\title{
The response of the terrestrial biosphere to urbanization: land cover conversion, climate, and urban pollution
}

\author{
K. Trusilova and G. Churkina \\ Max-Planck Institute for Biogeochemistry, Hans-Knoell Str. 10, 07745 Jena, Germany \\ Received: 19 March 2008 - Published in Biogeosciences Discuss.: 9 June 2008 \\ Revised: 3 September 2008 - Accepted: 11 April 2008 - Published: 4 November 2008
}

\begin{abstract}
Although urban areas occupy a relatively small fraction of land, they produce major disturbances of the carbon cycle through land use change, climate modification, and atmospheric pollution. In this study we quantify effects of urban areas on the carbon cycle in Europe. Among urbanization-driven environmental changes, which influence carbon sequestration in the terrestrial biosphere, we account for: (1) proportion of land covered by impervious materials, (2) local urban meteorological conditions, (3) urban high $\mathrm{CO}_{2}$ concentrations, and (4) elevated atmospheric nitrogen deposition. We use the terrestrial ecosystem model BIOMEBGC to estimate fluxes of carbon exchange between the biosphere and the atmosphere in response to these urban factors.

We analysed four urbanization-driven changes individually, setting up our model in such a way that only one of the four was active at a time. From these model simulations we found that fertilization effects from the elevated $\mathrm{CO}_{2}$ and the atmospheric nitrogen deposition made the strongest positive contributions to the carbon uptake $\left(0.023 \mathrm{Pg} \mathrm{C} \mathrm{year}^{-1}\right.$ and $0.039 \mathrm{PgC}_{\mathrm{Cear}}{ }^{-1}$, respectively), whereas, the impervious urban land and local urban meteorological conditions resulted in a reduction of carbon uptake $\left(-0.005 \mathrm{Pg} \mathrm{C}_{\text {year }}{ }^{-1}\right.$ and $-0.007 \mathrm{PgC}_{\text {year }}{ }^{-1}$, respectively). The synergetic effect of the four urbanization-induced changes was an increase of the carbon sequestration in Europe of $0.058 \mathrm{Pg} \mathrm{C}_{\text {year }}{ }^{-1}$.
\end{abstract}

\section{Introduction}

Urban population is growing at a much faster rate than the Earth's total population (WRI, 1996) and this leads to the growth of urban areas and often to an increase of urban pollution. Effect of urbanization on vegetation cover depends

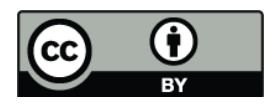

Correspondence to: $\mathrm{K}$. Trusilova (ktrusil@bgc-jena.mpg.de) on the form of urbanization and climatic region. Low density housing development may increase vegetation fraction and potential carbon uptake, e.g. if lawns and gardens replace agricultural fields. In desert and semi-desert regions urbanization also leads to an increase in vegetation cover. For Europe in particular, declining of vegetated land caused by urban growth was documented in the report of Lavalle et al. (2002). As urban areas continue to grow potential carbon sink on land is shrinking because vegetated land is replaced by land covered with impervious materials (buildings, roads, parking lots, etc.). Although urban areas occupy a small land fraction of about $2-3 \%$ of the Earth's surface (WRI, 1998), they are sources of about $90 \%$ of anthropogenic carbon dioxide $\left(\mathrm{CO}_{2}\right)$ globally. In Europe, about $70 \%$ of nitrogen dioxide emissions are attributed to traffic (USGS, 1999) and, thus, to urbanized land. At the same time, due to high energy consumption and often lack of evaporation, a warmer and drier microclimate is maintained within urban areas. All consequences of urban development mentioned above have a great potential to influence the carbon cycle and to cause irreversible damage to the surrounding land ecosystems.

Attempts to quantify the role of urban areas on the global carbon budget have focused largely on emissions inventories and carbon sequestration in urban ecosystems. Earlier studies focused on different but single aspects of urbanization and its effects on our environment such as land use modifications (USGS, 1999), global climate change (Parker, 2004; Jones et al., 1990; Wood, 1988; Kukla et al., 1986), climate modifications at regional and local scales (Trusilova et al., 2008; Lamptey et al., 2005), and atmospheric pollution (ESA, 2004; Koerner and Klopatek, 2002; WRI, 1998). It was found that the enrichment of atmospheric $\mathrm{CO}_{2}$ results in an increased Net Primary Productivity (NPP) of plants (Idso and Kimball, 2001; Hollinger et al., 1999; Dewees and Saxena, 1995). Significant fertilisation effects of atmospheric nitrogen were described in the work of Churkina et al. (2007). However, little research was done on investigating

Published by Copernicus Publications on behalf of the European Geosciences Union. 
the synergetic effects of these two and the urban climate on the land biosphere. One of the major difficulties in quantifying such synergetic effects is that urbanization affects the environment on different scales: from local (land use change) and regional (urban climate) to continental (high concentrations of $\mathrm{CO}_{2}$ and nitrogen compounds).

In this study we estimate synergetic effects of local-, regional- and continental-scale changes driven by urbanization on the terrestrial biosphere in Europe. We use a biogeochemical terrestrial ecosystem model BIOME-BGC to estimate responses in the net carbon flux to the urbanizationdriven changes in land cover, climate, atmospheric $\mathrm{CO}_{2}$ concentrations, atmospheric deposition of nitrogen that comes from oxides of nitrogen $\left(\mathrm{NO}_{\mathrm{x}}\right)$ produced during combustion, and the synergetic effect of all these four changes together. We chose to include only nitrogen and $\mathrm{CO}_{2}$ fertilisation effects in our simulations because those are direct effects which are well represented by a variety of process-based biosphere models.

In this study we omitted including damaging effects of ozone on vegetation growth (Chameides et al., 1994) because ozone has short lifetime of 1-2 days, its concentrations tend to be highest in urban areas and, thus, it affects urban vegetation very locally; mechanisms of these effects are not well understood and are poorly represented in biosphere models. Therefore we most likely slightly overestimate carbon sink in the simulation with all environmental changes included.

\section{Materials and methods}

\subsection{Model}

The terrestrial ecosystem model BIOME-BGC (Trusilova and Churkina, 2008; Thornton et al., 2002; Thornton, 1998; Running, 1994; Running and Gower, 1991; Running and Hunt, 1991; Running and Coughlan, 1988) was used to estimate carbon fluxes from vegetation to the atmosphere. The model simulates daily carbon, nitrogen, and water cycles through land ecosystems. This process-based model is driven by daily meteorological data such as maximum and minimum daily temperature, precipitation, vapour pressure deficit, and solar radiation. The land surface is parameterized using a digital elevation map, soil texture data, land cover classification including eight plant functional types, atmospheric $\mathrm{CO}_{2}$ concentrations and the atmospheric deposition of nitrogen. Each plant functional type is described by ecophysiological parameters.

For this study we defined urban land as in the Corine Land Cover 2000 database (CLC2000, http://terrestrial.eionet. europa.eu/CLC2000): urban land includes areas mainly occupied by dwellings and buildings including their connected areas (associated lands, road network, and parking-lots), rail networks, airport installations, river and sea port installations, industrial livestock rearing facilities, construction sites, man-made waste dump sites, urban parks, sport and leisure facilities (Bossard et al., 2000). As the CLC2000 urban land mask has resolution of $250 \mathrm{~m}$, this data had to be upscaled to the model resolution.

Effects of urban pollution and climate changes were indirectly included in the simulations as "urban effects". This was done by introducing a relevant change into the input data of the model: (1) urban land fraction as percentage of barren land in the land-use map, (2) bias in temperature and precipitation in the meteorological input dataset for representing urban climate, (3) local elevated urban $\mathrm{CO}_{2}$ concentrations, and (4) elevated atmospheric nitrogen due to human activities.

\subsection{The model simulations}

The model domain for this study covers most of Europe, $15^{\circ} \mathrm{W}-45^{\circ} \mathrm{E} 30^{\circ} \mathrm{N}-60^{\circ} \mathrm{N}$, with a spatial resolution of 0.25 degrees for the land surface data and meteorological fields. The meteorological dataset was generated with the regional climate model REMO (Jacob and Podzun, 1997) for multidecadal atmospheric modelling for Europe: the REMO simulations were performed on a rotated spherical grid with a horizontal resolution of 0.5 degrees that corresponds to about $47-55 \mathrm{~km}$ in the zonal direction and $55 \mathrm{~km}$ in the meridional direction. The full model output was stored hourly (Feser et al., 2001); then, the data was disintegrated to the spatial resolution of 0.25 degrees by Chen et al. (2007).

The REMO model has no explicit urban area definition and no specific land surface scheme for urban land cover. Urban areas are only implicitly included in REMO through the land surface parameters: roughness length $(2.5 \mathrm{~m})$, albedo $(0.2)$, zero vegetation fraction, and zero water holding capacity. The land surface parameters for each grid cell were averaged from the data on $1 \mathrm{~km}$ spatial resolution. Thus, for large grid cells on 0.5 degrees resolution few grid cells with urban land cover had a minor effect on the climate. These data were aggregated to the daily time step and included minimum and maximum daily temperature, daily precipitation, downward shortwave solar radiation, and air relative humidity.

The USGS global land cover product (Global Land Cover Characterization from U.S. Geological Survey) was used to prepare the map of eight vegetation land cover classes that correspond to the plant functional types resolved by the BIOME-BGC model.

As the BIOME-BGC model does not explicitly resolve urban land cover all urban areas were parameterized as barren surfaces with a small vegetation fraction. We used the same vegetation fraction value, 0.15 , as in the work of Trusilova et al. (2008) that was calculated based on the data from Lavalle et al. (2002) for the urban mask on $10 \mathrm{~km}$ resolution. This mask of urban land was upscaled to the resolution of 0.25 degrees for this study; for each grid cell of the model domain the urban land fraction was calculated. Only this fraction was assumed urban, not the whole grid cell. 


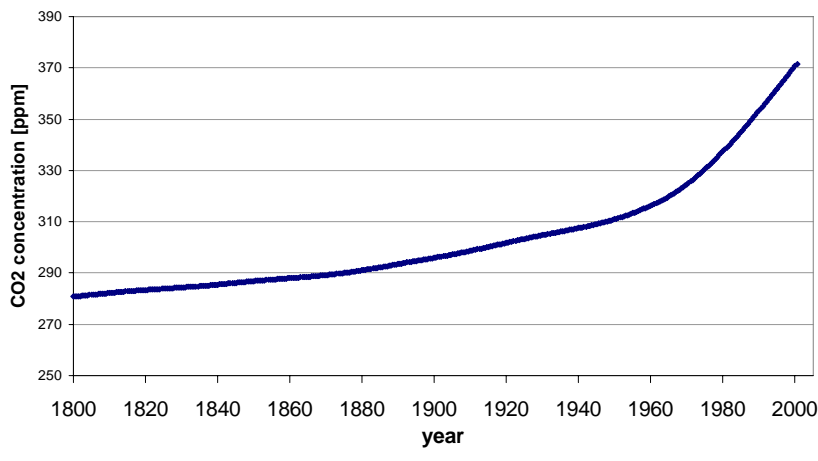

Fig. 1. Background atmospheric $\mathrm{CO}_{2}$ concentration [ppm] rise used in simulations with the BIOME-BGC model. For each year, one concentration value is uniformly used for all model grid cells assuming that the atmosphere is well-mixed. Data source: CARBOEUROPE-IP database.

\subsubsection{Spinup simulation}

Carbon and nitrogen state variables of the BIOME-BGC model represent amounts of carbon or nitrogen stored in simulated plant and soil pools. Unless values for the initialization of the model's state variables are available from measurements, model simulations are required for their initialization (spinup run). In the spinup run, the model is run to a steady state to obtain the size of the ecosystem's carbon and nitrogen pools under the assumption of the ecosystem being in equilibrium with the long-term climate. In this simulation the $\mathrm{CO}_{2}$ concentration was set to a preindustrial level of 283 ppm (Fig. 1), the annual nitrogen atmospheric deposition was set to a constant of $2 \mathrm{kgN} \mathrm{ha}^{-1}$, the highest pre-industrial estimate reported by Holland et al. (1999). The meteorological data of 1958-1977 were replicated throughout the spinup simulation. This meteorological data of 20 years were chosen because of three following reasons:

(1) the regional model REMO required the lateral boundary forcing that was first available from 1958 on (ECMWF reanalysis),

(2) these data do not contain any significant temperature trend attributed to the global warming,

(3) the period $1958-1977$ is sufficiently long to include the variations of incoming shortwave radiation related to the solar cycle that is of great importance for plant growth.

The spinup run was done for each grid cell of the model domain independently (there is no spatial dependence between model grid cells), until the carbon balance of the ecosystem reached its equilibrium state.

\subsubsection{Transient simulation}

After the spinup simulation, a transient model simulation was performed for 1800-1957 with repeated meteorological data from 1958-1977, atmospheric nitrogen deposition gradually rising (Galloway et al., 2004), and with the increasing annual
Table 1. . Model setup for simulating different urbanization-driven changes of the terrestrial biosphere. Different urban factors were switched on $(\mathrm{Y})$ and off $(\mathrm{N})$ at the time of model simulations.

\begin{tabular}{|c|c|c|c|c|c|}
\hline \multirow{2}{*}{ Simulation } & \multirow{2}{*}{ Description } & \multicolumn{4}{|c|}{ Disturbances } \\
\hline & & $\begin{array}{l}\text { Urban } \\
\text { land }\end{array}$ & $\begin{array}{l}\text { Urban } \\
\text { climate } \\
\text { bias }\end{array}$ & $\begin{array}{l}\text { Urban } \\
\mathrm{CO}_{2} \\
\text { increment }\end{array}$ & $\begin{array}{l}\text { Atm. } \\
\text { nitrogen } \\
\text { deposition }\end{array}$ \\
\hline NOU & $\begin{array}{l}\text { Baseline } \\
\text { simulation }\end{array}$ & $\mathrm{N}$ & $\mathrm{N}$ & $\mathrm{N}$ & $\mathrm{N}$ \\
\hline ULAND & $\begin{array}{l}\text { Effects of } \\
\text { urban land }\end{array}$ & $\mathrm{Y}$ & $\mathrm{N}$ & $\mathrm{N}$ & $\mathrm{N}$ \\
\hline UMET & $\begin{array}{l}\text { Effects of urban } \\
\text { warm and dry } \\
\text { environment }\end{array}$ & $\mathrm{N}$ & $\mathrm{Y}$ & $\mathrm{N}$ & $\mathrm{N}$ \\
\hline $\mathrm{UCO} 2$ & $\begin{array}{l}\text { Effects of urban } \\
\text { elevated } \mathrm{CO}_{2} \\
\text { concentrations }\end{array}$ & $\mathrm{N}$ & $\mathrm{N}$ & $\mathrm{Y}$ & $\mathrm{N}$ \\
\hline UAND & $\begin{array}{l}\text { Effects of elevated } \\
\text { atm. nitrogen } \\
\text { deposition }\end{array}$ & $\mathrm{N}$ & $\mathrm{N}$ & $\mathrm{N}$ & $\mathrm{Y}$ \\
\hline UALL & $\begin{array}{l}\text { Synergetic effect } \\
\text { of all four factors }\end{array}$ & $\mathrm{Y}$ & $\mathrm{Y}$ & $\mathrm{Y}$ & $\mathrm{Y}$ \\
\hline
\end{tabular}

mean atmospheric $\mathrm{CO}_{2}$ supplied by the CARBOEUROPEIP project (http://www.carboeurope.org/). The atmospheric $\mathrm{CO}_{2}$ concentration (Fig. 1) represents a smooth change in the well mixed atmosphere and was used as the background value for all following model simulations. The carbon dioxide concentration within the model was updated annually using the same background value for all grid cells. The state variables from the transient simulation ending in 1957 were used as starting point for subsequent simulations from 1958 to 2003 that include different urban effects.

\subsubsection{Simulation of urbanization-driven changes}

In order to isolate effects of individual urbanization-driven changes on the terrestrial net ecosystem exchange of carbon during the time from 1958 to 2003, six model simulations were performed. Model drivers for each simulation were set up in such a way that they represented none, one, or all urbanization effects (Table 1).

The NOU-simulation was the reference model run, which included no changes due to urbanization. Each of UMET, ULAND, UAND, and UCO2 simulations included one of the urbanization-driven changes such as urban land, urban climate bias, elevated carbon dioxide concentrations, and atmospheric nitrogen deposition, respectively. The UALL simulation represented a synergetic effect of all individual urbanrelated changes of the terrestrial biosphere.

For the baseline NOU-simulation the atmospheric nitrogen deposition was fixed at the level of 1958, the atmospheric $\mathrm{CO}_{2}$ concentration was set at the level of $294.8 \mathrm{ppm}$ (year 1958) assuming no rise throughout the simulation. The NOU-land-cover map, which includes no urban land, was used. No additional urban change was introduced to the meteorological data fields of the model. 


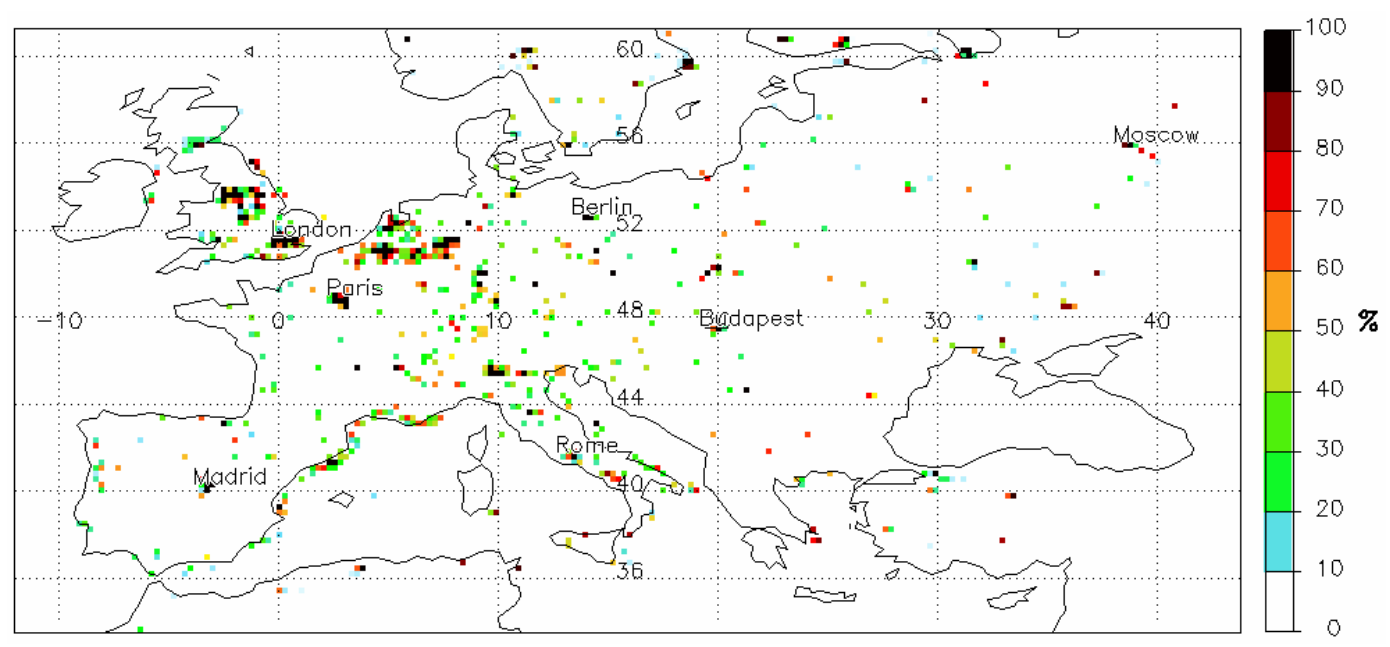

Fig. 2. Fraction of urban land [\%] in grid cells of the model domain. Spatial resolution of the grid cell is $0.25 \times 0.25$ degrees.

ULAND-simulation. The ecosystem carbon fluxes of the ULAND simulation were calculated with the model setup as in the NOU simulation with the only difference being that a part of these fluxes proportional to the fraction of urban land (Fig. 2) was subtracted. As in this study we assumed that urban areas had just the small vegetation fraction it was expected that urban land acts as a source rather than a sink of carbon; $2.8 \%$ of the total land in the model domain was urban.

UMET-simulation. The landscape alteration through urbanization involves the transformation of the radiative and aerodynamic characteristics of the land surface and results in changes of the water cycle and planetary boundary layer. Such altered environments are likely to experience extreme temperatures (Gonzalez et al., 2005; Jin et al., 2005; Ca et al., 1998; Jauregui, 1991; Huang et al., 1987; Bernatzky, 1982) and urban heat island phenomena (Atkinson, 2003; Borghi et al., 2000; Brunetti et al., 2000) as well as changes of precipitation (Dixon and Mote, 2003; Rosenfeld, 2000; Huff and Changnon, 1973) and reduced air moisture and evaporation in cities (Mayer et al., 2003; Grimmond and Oke, 1999). Quantitative estimates of the effects of urban land on the local climate were taken from the study of Trusilova et al. (2008), who analysed differences in near-surface temperature and precipitation between an undisturbed (without urban land) and a present day atmospheric circulation in Europe. It was found that the conversion of rural to urban land results in statistically significant reduction of the diurnal temperature range by $1.26 \pm 0.71^{\circ} \mathrm{C}$ in summer and by $0.73 \pm 0.54^{\circ} \mathrm{C}$ in wintertime as well as changes of precipitation (an increase in winter by $+0.09 \pm 0.16 \mathrm{~mm} \mathrm{day}^{-1}$ and a reduction in summer by $0.05 \pm 0.22 \mathrm{~mm} \mathrm{day}^{-1}$ ). These estimates were calculated assuming that all urban areas have homogeneous structure: all buildings are of the same height and all street canyons of the same shape. The urban surface scheme used by Trusilova et al. (2008) was generalized in order to represent large horizontal scales (10-100 km) and to be able to capture radiative budgets, momentum, turbulent heat and ground fluxes from heterogeneous urban surfaces. Such generalisation allowed model applicability for multiple urban areas in the large model domain.

The extracted maps of urbanization-induced changes for temperature and precipitation were superimposed on the input meteorological fields for the BIOME-BGC model.

UCO2-simulation. Near the surface, large urban clusters often are "hot spots" of intensive $\mathrm{CO}_{2}$ release from diffuse sources of anthropogenic origin (Koerner and Klopatek, 2002; Idso et al., 2001): transport network, industrial emissions etc. Scarce measurements of urban $\mathrm{CO}_{2}$ are available that were taken in various locations and times with different instrumental setups. In the study of Rome, Italy (Gratani and Varone, 2005) carried out through 1995, 1998, and 20012004, $\mathrm{CO}_{2}$ concentrations measured on the street level of $2 \mathrm{~m}$ above ground in the city were by $15 \%-23 \%$ higher than in the baseline $\mathrm{CO}_{2}$ concentration (NOU-simulation). In the study of Krakow, Poland (Zimnoch et al., 2004) in 1994, measurements of $24 \%$ higher urban $\mathrm{CO}_{2}$ were registered at $20 \mathrm{~m}$ above ground level, in the area without direct lowemission sources and without car traffic nearby. The highest $\mathrm{CO}_{2}$ concentrations were registered in Paris, France (Widory and Javoy, 2003) at few metres above ground level in shortterm campaigns in 1997-1998 that was higher by $7 \%-220 \%$ than the background value. The measurement campaign that has been conducted in the Metropolitan area of Copenhagen in 2000-2002 registered up to $86 \%$ higher $\mathrm{CO}_{2}$ concentrations at the level of $10 \mathrm{~m}$ above ground in urban core relative to suburban areas. All mentioned above studies relate the highest $\mathrm{CO}_{2}$ values mainly to the vehicle exhausts. Following this assumption we have constructed an approximation of the urban-to-rural $\mathrm{CO}_{2}$ concentration increment $\left(\Delta \mathrm{CO}_{2}\right)$ using the urban land mask. We used the updated urban mask (Trusilova et al., 2008) that includes information about the 


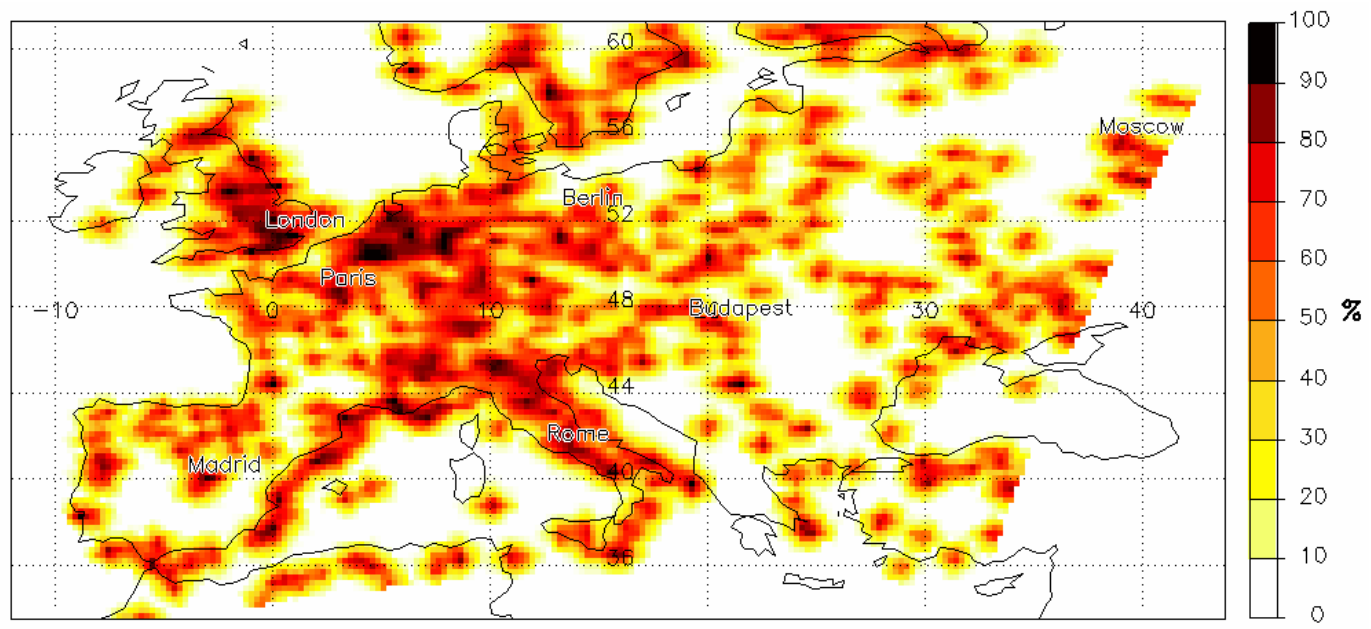

Fig. 3. The spatial distribution of $\Delta \mathrm{CO}_{2}$ - increment of urban carbon dioxide concentration in relation to the background rural value [\%] in carbon dioxide concentrations $\left(\Delta \mathrm{CO}_{2}\right)$ between urban and rural land relative to the background $\mathrm{CO}_{2}$ concentration.

population density and light emissions data as a proxy for constructing $\Delta \mathrm{CO}_{2}$. The main principle for this construction is: the larger the proportion of urban land in a gridcell the higher is the $\mathrm{CO}_{2}$ emissions and as follows the $\mathrm{CO}_{2}$ concentrations. Applying this principle requires the assumption that the $\mathrm{CO}_{2}$ exhaust intensity is the same across all urban pixels in Europe. The estimation of $\Delta \mathrm{CO}_{2}$ was done for the street level (several metres above ground) where most of vegetation will be affected by it. For such rough estimate at this height no atmospheric transport model was needed to resolve vertical and horizontal gradients in $\Delta \mathrm{CO}_{2}$ distribution. We assumed the homogeneous vertical distribution of $\Delta \mathrm{CO}_{2}$ within the first several metres above ground $(<10)$; the horizontal gradients were estimated using the urban land fraction data. Taking into account the reported magnitude of the $\mathrm{CO}_{2}$ concentrations we constructed a map of urban-torural $\triangle \mathrm{CO}_{2}$ that was calculated from the fraction of urban land (Fig. 3):

$\Delta \mathrm{CO}_{2}[i, j]=\Delta \mathrm{co}_{2} \frac{1}{(2 r+1)^{2}} \int_{i-r}^{i+r} \int_{j-r}^{j+r} S_{\mathrm{urb}}[i, j] d x d y$,

where $i, j$ - grid cell coordinates, $r$ - distance of the smoothing of influence, $r=2$; it insures that neighbour pixels do not get extremely different values, $S_{\mathrm{urb}}[i, j]$ - urban area within the $r$-distance from the centre in the pixel $[i, j]$; devided by the $(2 r+1)^{2}$ gives the fraction of urban land in the area defined by $[i-r, i+r]$ and $[j-r, j+r]$,

$\Delta \mathrm{co}_{2}$ - proportion of the $\mathrm{CO}_{2}$ increment per one urban grid cell [\%] as approximated from the available measurements in the following way: from the assumed linear relationship between the size of the city and the magnitude of the $\mathrm{CO}_{2}$ increment (for a city $10 \times 10$ pixels large it was $100 \%$, for a city 10 pixels large it was $32 \%$ ).
The $\Delta \mathrm{CO}_{2}$ was then used as an additional model input and included into the calculation of total input $\mathrm{CO}_{2}$ concentration for each grid cell as:

Input_CO $\mathrm{CO}_{2}[i, j]=$ Background_CO $\mathrm{CO}_{2} \times\left(1+\Delta \mathrm{CO}_{2}[i, j]\right)$,

where Input_ $\mathrm{CO}_{2}$ is the $\mathrm{CO}_{2}$ concentration value for a grid cell $[i, j]$, and Background $\mathrm{CO}_{2}$ is the input annual background carbon dioxide concentration (the same value for all grid cells throughout the simulation).

UAND-simulation. In contrast to the NOU-simulation, the data on dry atmospheric nitrogen deposition for the UANDsimulation corresponds to the year 2003. As the model was run from 1958 to 2003, the nitrogen deposition was gradually interpolated from the value at the beginning of the simulation (Fig. 4a) to the value in the end of the simulation (Fig. 4b) for each model pixel. This yielded an additional input of $8.86 \mathrm{Tg}$ of nitrogen over 46 years in the model domain.

The UALL-simulation was performed with all four urbanization-driven changes included: the elevated $\mathrm{CO}_{2}$ concentrations, the rising nitrogen deposition, fraction of urban land, and the urbanization-induced changes in local climate. As the BIOME-BGC model simulates interactions of carbon, nitrogen, and water cycles, including all four urban factors represented the synergetic effect of urban pollution, land use, and local climate on the carbon sequestration of European land ecosystems.

\section{Analysis of model output}

In order to quantify responses of the land ecosystems we analysed the following carbon fluxes calculated by the BIOME-BGC model: Net Ecosystem Exchange (NEE), Gross Primary Production (GPP), and Total Ecosystem Respiration (TER). The latter was calculated as a sum of 

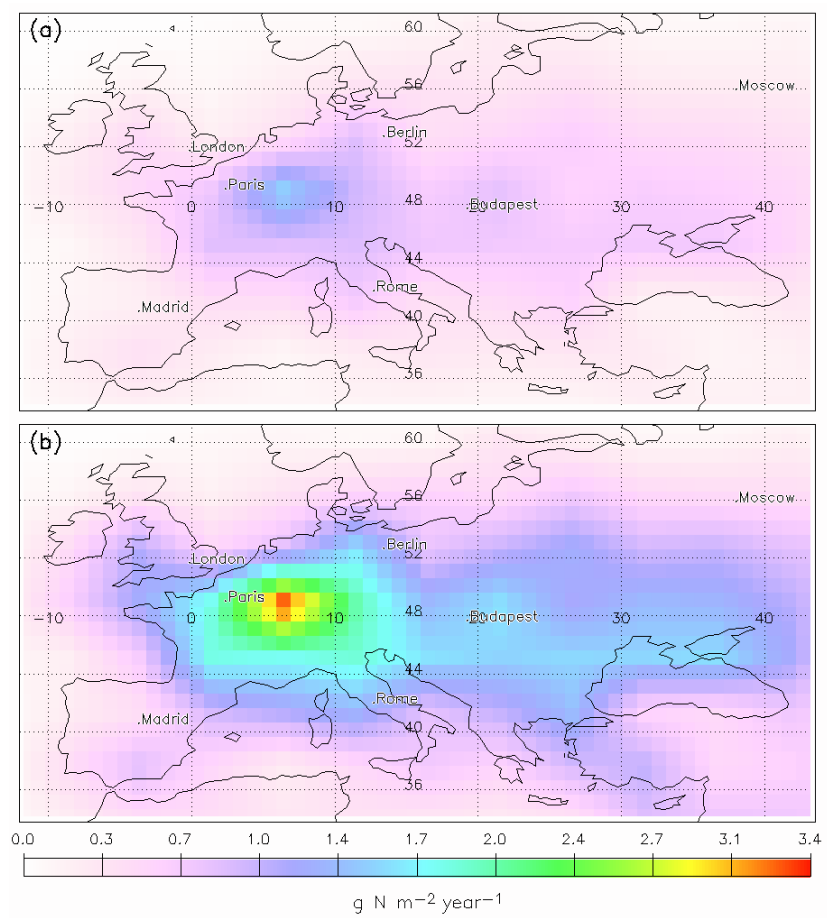

Fig. 4. Dry nitrogen atmospheric deposition $\left[\mathrm{g} \mathrm{N} \mathrm{m}^{-2}\right.$ year $\left.^{-1}\right]$ in 1958 (a) and 2003 (b). Data source Galloway et al. (2004).

heterotrophic respiration, plant growth respiration, and maintenance respiration.

We calculated differences in modelled carbon fluxes from each of the simulations ULAND-, UMET-, UCO2-, and UAND- and the baseline NOU-simulation. We used these differences as quantitative estimates of the sensitivity of the carbon fluxes to the respective urbanization-driven change. The flux difference between the UALL and NOU simulations was interpreted as the response of the biosphere to all counteracting urban changes together.

We calculated the total difference in the GPP, TER, and NEE over the model domain as the sum over differences in individual pixels:

$C(\mathrm{FLX}, \operatorname{sim})=\frac{1}{\mathrm{~N}} \int_{d t} \int_{d S}(\mathrm{flx}(\mathrm{FLX}, \operatorname{sim})-\mathrm{flx}(\mathrm{FLX}, \mathrm{NOU})) d S d t$,

$C$ (FLX,sim) - yearly average amount of carbon attributed to the flux FLX in the simulation sim,

FLX - GPP, TER or NEE flux in the simulation sim,

sim=ULAND | UMET | UAND | UCO2 | UALL simulation, $\mathrm{N}$ - total number of simulated years $(\mathrm{N}=46)$,

flx (FLX, sim) - flux FLX of one the grid cell in the simulation sim, $\left[\mathrm{Pg} \mathrm{C} \mathrm{m}^{-2}\right.$ year $\left.^{-1}\right]$,

$S-$ area of model domain, $\left[\mathrm{m}^{2}\right]$,

$t$-time, [year].

\section{Results and discussion}

Model simulations were performed according to the six setups described above. Modelled GPP, NEE, and TER fluxes from simulations ULAND, UMET, UCO2, UAND, and UALL were analysed in relation to the baseline simulation NOU. The differences between each simulation that includes urban factor(s) and the baseline were interpreted as a quantitative measure of the effect of the respective urbanizationinduced change on biosphere.

\subsection{Land cover}

The conversion of vegetated land to urban caused a reduction of GPP (Fig. 5a1), TER (not shown) and NEE (Fig. 5a2) over perturbed land. The average reduction of the NEE flux over simulated period was $-0.005 \mathrm{Pg} \mathrm{C}_{\text {year }}{ }^{-1}$ in Europe (model domain). This reduction accounted for $0.3 \%$ of the yearly average NEE from the relevant area. In this estimate all urban areas have the same vegetation fraction. In reality cities have a blend of land cover types such as trees, grasses, barren, and impervious surfaces in different proportions. To account for the heterogeneity of urban vegetation and its role in the carbon cycle we would have to use very precise satellitederived maps of urban land cover on fine spatial resolutions of $1-10 \mathrm{~m}$. For example, an estimation of total reduction of net primary production (NPP) in the southeastern US was made by Milesi et al. (2003). Using a remote sensing based methodology, the authors found that an increase in urban development of $1.9 \%$ over $1990-2000$ resulted in a reduction of NPP by $0.4 \%$ over the region. However, the heterogeneity of urban land covers also involves a wider set of model setups in order to represent the full variety of urban ecosystems in our modelling study and it would generate large uncertainties in carbon flux estimates. Thus we focused on a general estimate of the urban effects on the European carbon cycle and, thus, used a rather simplified representation of urban land cover.

\subsection{Climate}

Responses of GPP and TER fluxes to the urbanizationinduced changes in the climate were spatially heterogeneous. In most areas of reduced precipitation GPP and TER flux (growth respiration and heterotrophic respiration components) were reduced. However, the photosynthetic productivity was higher in areas with enhanced precipitation and increased temperature and resulted in local peaks of GPP (Fig. 5b1). The range for GPP changes was $-0.22 \pm 0.41 \mathrm{~kg} \mathrm{C} \mathrm{m}^{-2}$ year $^{-1}$ and for TER $-0.20 \pm 0.40 \mathrm{~kg} \mathrm{C} \mathrm{m}^{-2}$ year $^{-1}$. Since the areas of GPP reduction were larger in extent, they dominated the overall average change in carbon balance $-0.007 \mathrm{Pg} \mathrm{C}_{\text {year }}{ }^{-1}$ over $\mathrm{Eu}-$ rope. This could partly be explained by the high sensitivity of the BIOME-BGC model to the soil water availability; the 

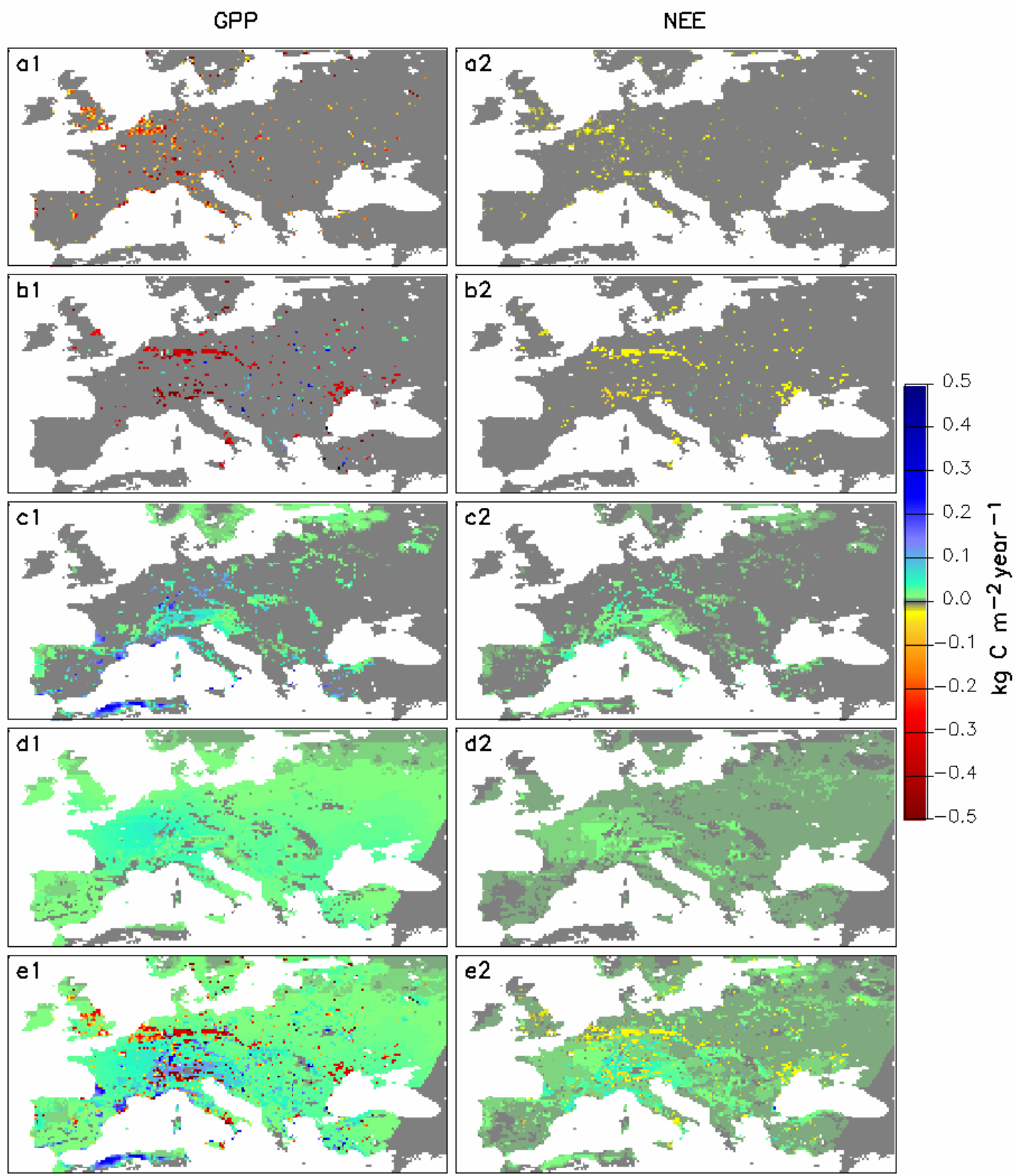

Fig. 5. Response of GPP (a1, b1, c1, d1, e1) and NEE (a2, b2, c2, d2, e2) fluxes to different urbanization-driven changes: urban land (a1, a2), urban climate (b1, b2), urban $\mathrm{CO}_{2}(\mathrm{c} 1, \mathrm{c} 2)$, elevated nitrogen deposition (d1, d2), and all mentioned changes together (e1, e2).

reduced amount of precipitation leads to drying of soils and to the reduction in photosynthetic productivity of plants. The overall effect of climatic changes on carbon balance of Europe was negative and provided enhanced release of carbon from land ecosystems.

\subsection{Urban $\mathrm{CO}_{2}$}

An increase in carbon uptake of $(+0.01 \pm 0.01) \mathrm{kg} \mathrm{C} \mathrm{m}^{-2}$ year $^{-1}$ over large areas, with the highest values up to $0.10 \mathrm{~kg} \mathrm{C} \mathrm{m}^{-2}$ year $^{-1}$, were found in Central Europe where densely urbanized areas are located (Fig. 5c1 and 5c2). Effects of $\mathrm{CO}_{2}$ concentration on plants productivity were previously addressed in several studies. For example, Griffin et al. (2001) found that elevated $\mathrm{CO}_{2}$ produces significant changes in major cellular organelles of plants and lead to enhanced plant productivity. Taub et al. (2000) found that plants respond to the higher $\mathrm{CO}_{2}$ by increased thermotolerance of high-temperature stress; and that effect may have a substantial impact (increase) on productivity. Our simulations showed an average increment 


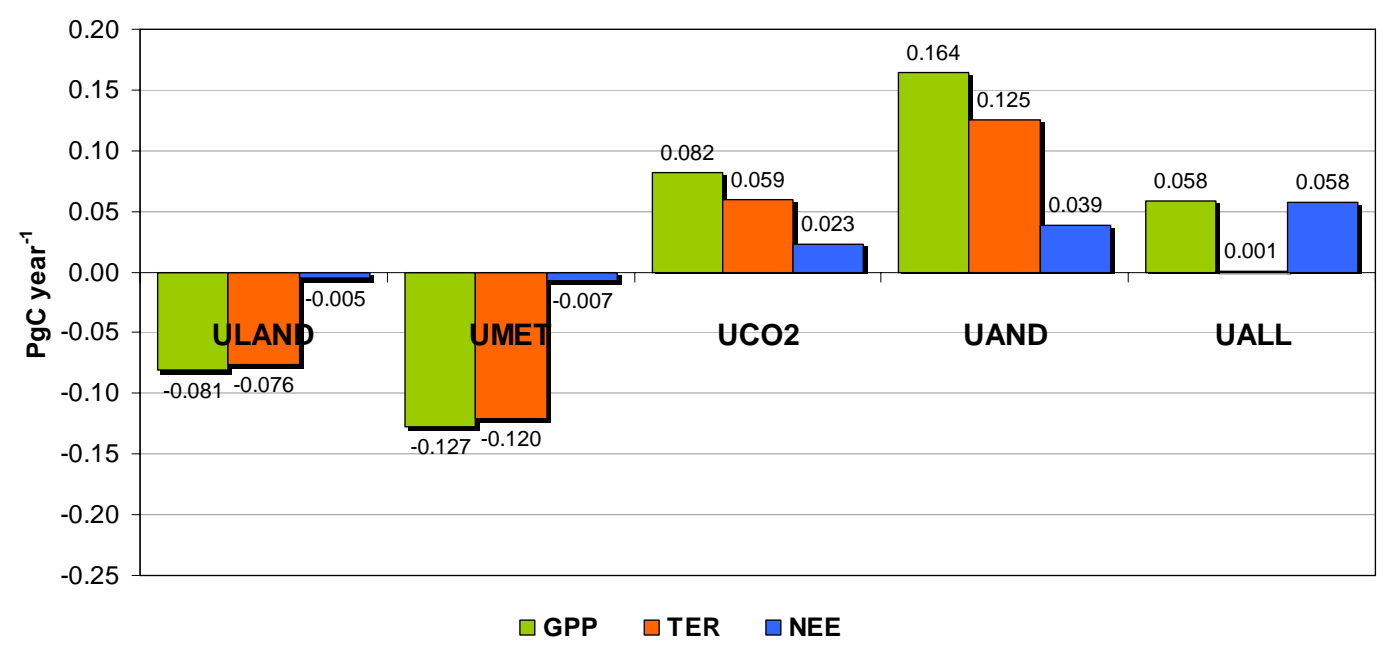

Fig. 6. Changes of carbon amount $\left[\mathrm{PgC}\right.$ year $\left.^{-1}\right]$ exchanged between the biosphere and the atmosphere in response to different urban disturbances: urban land (ULAND), urban meteorological bias (UMET), urban $\mathrm{CO}_{2}$ concentrations (UCO2), anthropogenic nitrogen deposition (UAND), and composition of all four disturbances (UALL). Data are 46-year averages of BIOME-BGC model output over 1958-2003.

of carbon sink by $0.023 \mathrm{PgC}$ year $^{-1}$ that was dominated by the increase in GPP (Fig. 6). This estimate reflects pure $\mathrm{CO}_{2}$ fertilization effect on ecosystems in urban and suburban ecosystems.

\subsection{Effects of elevated nitrogen deposition}

The sensitivity of the GPP flux to the additional atmospheric nitrogen deposition was the highest among all analysed urban changes $\left(+0.164 \mathrm{PgC}_{\mathrm{Cear}}{ }^{-1}\right)$. The additional nitrogen to the soils enhanced the microbial activity and lead to the higher heterotrophic respiration component of TER $\left(+0.125 \mathrm{PgC} \mathrm{year}^{-1}\right)$. The total net carbon flux (NEE) increased over the whole modelled domain by $0.039 \mathrm{Pg} \mathrm{C}_{\text {year }}{ }^{-1}$. This result is based on the model assumption that temperate and boreal vegetation is nitrogen limited (Vitousek et al., 2002). An increasing deposition of nitrogen from the atmosphere serves as a fertiliser for European ecosystems. Of all individual urbanization-driven changes studied here, nitrogen deposition has the strongest impacts on the total carbon balance. The role of atmospheric nitrogen deposition on the European carbon balance as a fertiliser is however debatable because of uncertainties of its effects on the agricultural land, which occupies a considerable proportion of Europe. In 1997 arable land together with permanent cropland and pasture covered $44 \%$ of EU15 (EUROSTAT, http://ec.europa.eu/agriculture/envir/report/en/terr_en/ report.htm). Agricultural land receives high loads of nitrogen directly as chemical fertilizer and therefore insensitive to the increasing deposition of nitrogen from the atmosphere. In this study, we only looked at the effects of atmospheric nitrogen deposition assuming no additional nitrogen-fertilisers are applied on agricultural land. On the other hand, the fraction of agricultural land was declining, while fraction of forests was increasing in the last 50 years. The European forests are currently young and are in the re-growth stage. The total forest area of 30 European countries has increased by $6 \%$ between 1950 and 1990 (Nabuurs et al., 2003). The productivity of regrowing forests is especially sensitive to the increasing atmospheric nitrogen deposition (Churkina et al., 2007).

\subsection{Synergetic effects}

When all four urbanization-induced changes were applied at once, the biosphere responded with a $0.058 \mathrm{PgC} \mathrm{year}^{-1}$ increase of carbon sink. This increase in NEE resulted from an increase in GPP $\left(+0.058 \mathrm{Pg} \mathrm{C}_{\text {year }}{ }^{-1}\right)$ and the slight change in TER $\left(+0.001 \mathrm{PgC}\right.$ year $\left.^{-1}\right)$. As the vegetation was replaced by barren land the amount of the potential carbon source through growth respiration was reduced but compensated by the growth of urban fractional vegetation. In the whole model domain, the reduction of carbon sink due to urban land use and climate was compensated by an increase of carbon sink due to fertilisation by simultaneously increasing atmospheric $\mathrm{CO}_{2}$ and nitrogen deposition.

The synergetic effect of the urbanization-driven changes considered here led to a stronger increase of carbon sink than any of them individually (Fig. 6), because atmospheric $\mathrm{CO}_{2}$ and soil nitrogen availability co-limit productivity of land ecosystems. This finding is confirmed by field studies where nitrogen availability was shown to be a constraint to $\mathrm{CO}_{2}-$ induced stimulation of plant growth (Reich et al., 2006; Oren et al., 2001). Our results were also in accordance with results from several modelling studies (Churkina et al., 2007; Lloyd, 1999) where numerical models were employed to simulate response of biosphere carbon cycle on the continental level. Low availability of nitrogen in the soils suppresses 
the positive physiological response of plant growth to elevated $\mathrm{CO}_{2}$. Anthropogenic increase in nitrogen deposition enhances availability of nitrogen in soil and thus the response of plants to increasing atmospheric $\mathrm{CO}_{2}$. Increase in atmospheric nitrogen deposition has been shown to drive the sequestration of carbon by European forests (Magnani et al., 2007).

Relationships between the carbon sequestration rates, nitrogen input, and climate variables are nonlinear and due to this nonlinearity, the total effect on vegetation of all urbanization-related changes together was not equal to the sum of individual effects from individual changes.

\section{Summary and outlook}

In this study we analysed dynamics of carbon sink in Europe driven by urbanization-induced changes of land use, climate, concentrations of carbon dioxide and nitrogen deposition from the atmosphere. We used the BIOME-BGC terrestrial ecosystem model to calculate responses of the biosphere to the urban changes applied individually and all together. We did not include agricultural management such as fieldfertilisation with nitrogen compounds in our simulations.

The land use and urban climate changes affected rather small land areas while the urban $\mathrm{CO}_{2}$ and nitrogen pollution spread over larger areas. When all urban changes were applied at once, the synergetic effects were dominated by the fertilisation effects from the $\mathrm{CO}_{2}$ and nitrogen pollution and led to a net increase of carbon sink in Europe.

Acknowledgements. We acknowledge the scholarship provided by the Max-Planck Institute for Biogeochemistry for Kristina Trusilova. We thank the AIMES-NCAR (Analysis, Integration and Modeling of Earth System network) for providing the financial support for presenting results of this work at the Second Workshop on Urbanization Interactions with Biogeochemistry and Climate, Mexico City, Mexico, 9-10 September 2006.

Edited by: T. Laurila

\section{References}

Atkinson, B. W.: Numerical modelling of urban heat-island intensity, Bound.-Lay. Meteorol., 109, 285-310, 2003.

Bernatzky, A.: The Contribution of Trees and Green Spaces to a Town Climate, Energ. Buildings, 5, 1-10, 1982.

Borghi, S., Corbetta, G., and De Biase, L.: A heat island model for large urban areas and its application to Milan, Nuovo Cimento C, 23, 547-566, 2000.

Bossard, M., Feranec, J., and Otahel, J.: CORINE land cover technical guide - Addendum 2000, European Environment Agency, Technical Report 40, 2000.

Brunetti, M., Mangianti, F., Maugeri, M., and Nanni, T.: Urban heat island bias in Italian air temperature series, Nuovo Cimento C, 23, 423-431, 2000.
Ca, V. T., Asaeda, T., and Abu, E. M.: Reductions in air conditioning energy caused by a nearby park, Energ. Buildings, 29, 83-92, 1998.

Chameides, W. L., Kasibhatla, P. S., Yienger, J., and Levy, H.: Growth of Continental-Scale Metro-Agro-Plexes, Regional Ozone Pollution, and World Food-Production, Science, 264, 7477, 1994.

Chen, Y., Churkina, G., and Heimann, M., 2007: A comparison of regional climate variables between various data sources, in: Technical Reports - Max-Planck-Institut für Biogeochemie Jena, Max-Planck-Institut für Biogeochemie, 1-36, 2007.

Churkina, G., Trusilova, K., Vetter, M., and Dentener, F.: Contributions of nitrogen deposition and forest regrowth to terrestrial carbon uptake, Carbon Balance and Management, 2(5), doi:10.1186/1750-0680-2-5, 2007.

Dewees, P. A. and Saxena, N. C.: Wood product markets as incentives for farmer tree growing, in: Farms, Trees and Farmers, edited by: Arnold, J. E. M. and Dewees, P. A., Oxford University Press, 198-241, 1995.

Dixon, P. G. and Mote, T. L., : Patterns and causes of Atlanta's urban heat island-initiated precipitation, J. Appl. Meteorol., 42, 1273-1284, 2003.

ESA, 2004: NO2 pollution characteristic for Europe's sprawled urban areas: Nitrogen dioxide pollution, European Space Agency, 2004.

Feser, F., Weisse, R., and von Storch, H.: Multi-decadal atmospheric modeling for Europe yields multi-purpose data, EOS Transactions, 305-310, 2001.

Galloway, J. N., Dentener, F. J., Capone, D. G., Boyer, E. W., Howarth, R. W., Seitzinger, S. P., Asner, G. P., Cleveland, C. C., Green, P. A., Holland, E. A., Karl, D. M., Michaels, A. F., Porter, J. H., Townsend, A. R., and Vorosmarty, C. J.: Nitrogen cycles: past, present, and future, Biogeochemistry, 70, 153-226, 2004.

Gonzalez, J. E., Luvall, J. C., Rickman, D., Comarazamy, D., Picon, A., Harmsen, E., Parsiani, H., Vasquez, R. E., Ramirez, N., Williams, R, and Waide, R. W., 2005: Urban heat islands developing in coastal tropical cities, EOS, Transactions, American Geophysical Union, 86, p. 397, p. 403, 2005.

Gratani, L. and Varone, L.: Daily and seasonal variation of CO2 in the city of Rome in relationship with the traffic volume, Atmos. Environ., 39, 2619-2624, 2005.

Griffin, K. L., Anderson, O. R., Gastrich, M. D., Lewis, J. D., Lin, G. H., Schuster, W., Seemann, J. R., Tissue, D. T., Turnbull, M. H., and Whitehead, D.: Plant growth in elevated CO2 alters mitochondrial number and chloroplast fine structure, P. Natl. Acad. Sci. USA, 98, 2473-2478, 2001.

Grimmond, C. S. B. and Oke, T. R.: Evapotranspiration rates in urban areas, Proceedings of Impacts of Urban Growth on Surface Water and Groundwater Quality, Birmingham, IAHS, 1999.

Holland, E. A., Dentener, F. J., Braswell, B. H., and Sulzman, J. M.: Contemporary and pre-industrial global reactive nitrogen budgets. Biogeochemistry, 46, 7-43, 1999.

Hollinger, D. Y., Goltz, S. M., Davidson, E. A., Lee, J. T., Tu, K., and Valentine, H. T.: Seasonal patterns and environmental control of carbon dioxide and water vapour exchange in an ecotonal boreal forest, Global Change Biol., 5, 891-902, 1999. 
Huang, Y. J., Akbari, H., Taha, H., and Rosenfeld, A. H.: The Potential of Vegetation in Reducing Summer Cooling Loads in Residential Buildings, J. Clim. Appl. Meteorol., 26, 1103-1116, 1987.

Huff, F. A. and Changnon, S. A.: Precipitation Modification by Major Urban Areas, B. Am. Meteorol. Soc., 54, 1220-1232, 1973.

Idso, C. D., Idso, S. B., and Balling, R. C.: An intensive two-week study of an urban CO2 dome in Phoenix, Arizona, USA, Atmos. Environ., 35, 995-1000, 2001.

Idso, S. B. and Kimball, B. A.: CO2 enrichment of sour orange trees: 13 years and counting, Environ. Exp. Bot., 46, 147-153, 2001.

Jacob, D. and Podzun, R.: Sensitivity studies with the regional climate model REMO, Meteorol. Atmos. Phys., 63, 119-129, 1997.

Jauregui, E.: Influence of a Large Urban Park on Temperature and Convective Precipitation in a Tropical City, Energ. Buildings, 15, 457-463, 1991.

Jin, M. L., Dickinson, R. E., and Zhang, D. L.: The footprint of urban areas on global climate as characterized by MODIS, J. Climate, 18, 1551-1565, 2005.

Jones, P. D., Groisman, P. Y., Coughlan, M., Plummer, N., Wang, W. C., and Karl, T. R.: Assessment of Urbanization Effects in Time-Series of Surface Air-Temperature over Land, Nature, 347, 169-172, 1990.

Koerner, B. and Klopatek, J.: Anthropogenic and natural CO2 emission sources in an arid urban environment, Environ. Pollut., 116, S45-S51, 2002.

Kukla, G., Gavin, J., and Karl, T. R.: Urban Warming, J. Clim. Appl. Meteorol., 25, 1265-1270, 1986.

Lamptey, B. L., Barron, E. J., and Pollard, D.: Impacts of agriculture and urbanization on the climate of the Northeastern United States, Global Planet. Change, 49, 203-221, 2005.

Lavalle, C., Demicheli, L., Kasanko, M., McCormick, N., Barredo, J., Turchini, M., da Graca Saraiva, M., da Silva, F. N., Ramos, I. L., and Monteiro, F. P.: Towards an urban atlas, European Environment Agency Report, 2002.

Lloyd, J.: The CO2 dependence of photosynthesis, plant growth responses to elevated $\mathrm{CO} 2$ concentrations and their interaction with soil nutrient status, II. Temperate and boreal forest productivity and the combined effects of increasing $\mathrm{CO} 2$ concentrations and increased nitrogen deposition at a global scale, Funct. Ecol., 13, 439-459, 1999.

Magnani, F., Mencuccini, M., Borghetti, M., Berbigier, P., Berninger, F., Delzon, S., Grelle, A., Hari, P., Jarvis, P. G., Kolari, P., Kowalski, A. S., Lankreijer, H., Law, B. E., Lindroth, A., Loustau, D., Manca, G., Moncrieff, J. B., Rayment, M., Tedeschi, V., Valentini, R., and Grace, J.: The human footprint in the carbon cycle of temperate and boreal forests, Nature, 447, 848-850, 2007.

Mayer, H., Matzarakis, A., and Iziomon, M. G.: Spatio-temporal variability of moisture conditions within the Urban Canopy Layer, Theor. Appl. Climatol., 76, 165-179, 2003.

Milesi, C., Elvidge, C. D., Nemani, R. R., and Running, S. W.: Assessing the impact of urban land development on net primary productivity in the southeastern United States, Remote Sens. Environ., 86, 401-410, 2003.

Nabuurs, G. J., Schelhaas, M. J., Mohren, G. M. J., and Field, C. B.: Temporal evolution of the European forest sector carbon sink from 1950 to 1999, Global Change Biol., 9, 152-160, 2003.
Oren, R., Ellsworth, D. S., Johnsen, K. H., Phillips, N., Ewers, B. E., Maier, C., Schafer, K. V. R., McCarthy, H., Hendrey, G., McNulty, S. G., and Katul, G. G.: Soil fertility limits carbon sequestration by forest ecosystems in a $\mathrm{CO} 2$-enriched atmosphere, Nature, 411, 469-472, 2001.

Parker, D. E.: Climate - Large-scale warming is not urban, Nature, 432, 290-290, 2004.

Reich, P. B., Hobbie, S. E., Lee, T., Ellsworth, D. S., West, J. B., Tilman, D., Knops, J. M. H., Naeem, S., and Trost, J.: Nitrogen limitation constrains sustainability of ecosystem response to CO2, Nature, 440, 922-925, 2006.

Rosenfeld, D.: Suppression of rain and snow by urban and industrial air pollution, Science, 287, 1793-1796, 2000.

Running, S. W.: Testing Forest-Bgc Ecosystem Process Simulations across a Climatic Gradient in Oregon, Ecol. Appl., 4, 238-247, 1994.

Running, S. W. and Coughlan, J. C.: A General-Model of Forest Ecosystem Processes for Regional Applications .1. Hydrologic Balance, Canopy Gas-Exchange and Primary Production Processes, Ecol. Model., 42, 125-154, 1988.

Running, S. W. and Gower, S. T.: Forest-Bgc, a General-Model of Forest Ecosystem Processes for Regional Applications .2. Dynamic Carbon Allocation and Nitrogen Budgets, Tree Physiol., 9, 147-160, 1991.

Running, S. W. and Hunt Jr., E. R.: Generalization of a forest ecosystem process model for other biomes, BIOME-BGC, and an application for global-scale models, in: Scaling Physiological Processes: Leaf to Globe, edited by: Ehleringer, J. R. and Field, C. B., Academic Press, Inc., New York, 141-158, 1993.

Taub, D. R., Seemann, J. R., and Coleman, J. S.: Growth in elevated $\mathrm{CO} 2$ protects photosynthesis against high-temperature damage, Plant Cell Environ., 23, 649-656, 2000.

Thornton, P. E.: Regional Ecosystem Simulation: Combining Surface- and Satellite-Based Observations to Study Linkages between Terrestrial Energy and Mass Budgets, PhD thesis, Missoula, University of Montana, 231 pp., 1998.

Thornton, P. E., Law, B. E., Gholz, H. L., Clark, K. L., Falge, E., Ellsworth, D. S., Golstein, A. H., Monson, R. K., Hollinger, D., Falk, M., Chen, J., and Sparks, J. P.: Modeling and measuring the effects of disturbance history and climate on carbon and water budgets in evergreen needleleaf forests, Agr. Forest Meteorol., 113, 185-222, 2002.

Trusilova, K. and Churkina, G.: The Terrestrial Ecosystem Model GBIOME-BGCv1, Max-Planck Institute for Biogeochemistry, Technical Report 14, 2008.

Trusilova, K., Jung, M., Churkina, G., Karstens, U., Heimann, M., and Claussen, M.: Urbanization Impacts on the Climate in Europe: Numerical Experiments by the PSU/NCAR Mesoscale Model (MM5), J. Appl. Meteorol. Clim., 47, 1442-1455, 2008.

USGS: Analyzing Land Use Change In Urban Environments, U.S. Department of the Interior, U.S. Geological Survey, 188-199, 1999.

Vitousek, P. M., Hattenschwiler, S., Olander, L., and Allison, S.: Nitrogen and nature, Ambio, 31, 97-101, 2002.

Widory, D. and Javoy, M.: The carbon isotope composition of atmospheric CO2 in Paris, Earth Planet. Sc. Lett., 215, 289-298, 2003. 
Wood, F. B.: On the Need for Validation of the Jones Et-Al Temperature Trends with Respect to Urban Warming - Comment, Climatic Change, 12, 297-312, 1988.

WRI: World Resources 1996-97: The urban environment, in: World Resources Report, University Press for the World Resources Institute, Oxford, 400 pp., 1996.
WRI: World Resources 1998-99: Environmental change and human health, in: World Resources Report, Oxford University Press for the World Resources Institute, 384 pp., 1998.

Zimnoch, M., Florkowski, T., Necki, J. M., and Neubert, R. E. M.: Diurnal variability of $13 \mathrm{C}$ and $18 \mathrm{O}$ of atmospheric $\mathrm{CO} 2$ in the urban atmosphere of Krakow, Poland, Isot. Environ. Health S., 40, 129-143, 2004. 